\title{
Parodi Pada Iklan Televisi Axis Serial Iritology Melalui Pendekatan Format, Struktur, Gaya Dan Teknik Iklan
}

*Intan Swasti Gita Rachmawati ${ }^{1}$ Ana Rosmiati ${ }^{2}$

Fakultas Seni Rupa dan Desain Institut Seni Indonesia Surakarta (ISI) Surakarta1, 2

\begin{abstract}
Axis advertisement is an advertisement that uses a parody approach using cultural references and community habits, one of which is the Axis Serial Iritology advertisement. The issue in this study is about parody on Axis Serial Iritology television advertisement through format, structure, style, and advertising techniques with the aim of describing parody on Axis Serial Iritology television advertisements through advertising approach. The research method used is descriptive qualitative to analyze this advertisement based on the format, structure, style, and technique of advertising according to Vilanilam and Varghese. Advertising approach using problem-solution format, a slice of life, burlesque, and testimonial format are used in the Axis serial Iritology ad. The advertising structures used are vignette, comparison, and continue series, whereas the ad style used is dominantly comedy, however, there are some scenes that are inserted in fantasy style. The technique used in the Axis Iritology advertisement uses the touch of animation and special effects in the middle and end of the ad. Parody in advertisements can be the main attraction in presenting an ad.
\end{abstract}

Keywords: parody, advertisement, format, structure, style, technique

\begin{abstract}
Abstrak
Iklan Axis merupakan iklan yang menggunakan pendekatan parodi dengan menggunakan referensi budaya dan kebiasaan masyarakat, salah satunya adalah Iklan Axis Serial Iritology. Permasalahan dalam penelitian ini adalah bagaimana parodi pada iklan televisi Axis Serial Iritology melalui pendekatan format, struktur, gaya, dan teknik iklan dengan tujuan mendeskripsikan parodi pada iklan televisi Axis Serial Iritology melalui pendekatan iklan. Metode penelitian yang digunakan adalah kulitatif deskriptif untuk menganalilis iklan ini berdasarkan format, struktur, gaya dan teknik iklan menurut Vilanilam dan Varghase. Pendekatan iklan $\mathrm{m}$ format problem solution, slice of life, burlesque dan testimonial format digunakan dalam iklan Axis serial Iritology. Struktur iklan yang digunakan adalah vignette, comparison, dan continue series, sedangkan gaya iklan yang digunakan dominan comedy, namun ada beberapa scene yang disisipkan dengan gaya fantasy. Teknik yang digunakan dalam iklan Axis serial Iritology memakai sentuhan animasi dan special effect pada bagian tengah dan akhir iklan. Konsep parodi pada iklan ditambah dengan beberapa pendekatan format, struktur, gaya dan teknik membuat sebuah iklan lebih efektif untuk penyampaian pesan pada masyarakat.
\end{abstract}

Kata Kunci: parodi, iklan, format, struktur, gaya, teknik

Corresponding author.

E-mail: swasti.intan@gmail.com

This is an open-access article under the CC-BY-SA license 


\section{PENGANTAR}

Brand AXIS merupakan produk layanan telekomunikasi dari XL Axiata. Axis berhasil masuk dalam nominasi "Top Ten Most Popular Video Ads in Indonesia 2016" oleh Google Indonesia. Pengemasan konsep iklan yang mejerumus pada kegitan masyarakat pinggiran di perkotaan ditonjolkan dari iklan serial Iritology ini. Axis memiliki target audiensi yang bersegmentasi pada masyarakat menengah ke bawah, usia remaja hingga dewasa dengan pekerjaan rata-rata sebagai pelajar, pedagang mikro. Dikutip dari Kompas.com pada tanggal 2018, masyarakat kelas menengah ke bawah mendominasi penggunaan internet di Indonesia. Hasil tersebut didapat dari survei yang dilakukan oleh Asosiasi Penyelenggara Internet Indonesia (APJII) tentang penetrasi dan perilaku pengguna internet tahun 2017. Strata ekonomi sosial kelas menengah ke bawah mendominasi lebih dari tiga perempat total pengguna internet di Indonesia dengan persentase 74,62 persen. Konsep iklan Axis serial Irirtoligy sendiri cukup unik, dengan pengemasan humor yang dilebihkan dalam setiap iklannya serta setting latar yang relate dengan kehidupan masyarakat sehari-hari menjadikan iklan ini lebih menarik. Beberapa penggambaran scene parodi dalam iklan Axis yang ditambahkan dengan gaya komedi yang dilebihkan menjadikan highlight iklan ini. Konsep parody yang biasa dipakai untuk gaya sindiran diolah sedemikian rupa, sehingga menghasilkan iklan komedi yang relate di masyarakat.

Rumusan masalah pada penelitian ini adalah bagaimana menganalisa unsur parody pada iklan televise Axis serial Irirtology dengan pendekatan format, struktur, gaya dan teknik iklan. Metode kualitatif deskriptif digunakan untuk penggambaran kondisi realitas sosial di masyarakat dengan penjabaran secara rinci dan mendalam baik kondisi maupun proses serta hubungan saling keterkaitan mengenai hal-hal temuan pokok pada sasaran penelitian (H.B Sutopo, 2006 :179). Obyek penelitian adalah Iklan televise Axis serial Iritology dengan judul dengan judul Iritology No. 36 - Maha Guru Irit, Iritology No. 54 - Cekrek Upload, Iritology No. 72 - Axis Gaol, dan Iritology No. 81- Axis Kzl yang mulai tayang pada 2015. Pemilihan iklan Axis serial Iritology sendiri merujuk pada berbagai penghargaan yang didapatkan oleh serial iklan televise ini, serta konsep penggambaran relitas sosial dalam masyarakat dengan pendekatan humour exaggeration yang menjadikan highlight dari iklan ini lebih banyak 
ditonton dalam platform Youtube. Pengumpulan data dalam penelitian ini menggunakan dua sumber data yaitu primer dan sekunder. Analisis data dalam penelitian menggunakan metode kualitatif deskriptif. Langkah awal yang digunakan adalah pencarian data dan menetukan tema yang akan dimuat untuk penelitian. Langkah selanjutnya ialah memilah beberapa iklan yang sedang terkenal dan memiliki penonton cukup banyak dalam beberapa platform. Setelah memilah beberapa pertimbangan, iklan televisi Axis serial Iritoligy yang dipilih untuk bahan penelitian ini. Serial Iritology dirasa cukup menarik karena memiliki 4 iklan dengan tema promosi yang diangkat dari kosep irit dalam telekomunikasi di masyarakat. Penelitian iklan ini diamati secara audio dan visual serta menganalisa efektifitas pendekatan iklan yang diambil dari format, struktur, gaya dan teknik iklan kemudian menyimpulkan dengan idiom parodi dari iklan tersebut. Setelah itu, hasil dan kesimpulan dari penelitian ini didapat.

\section{PEMBAHASAN}

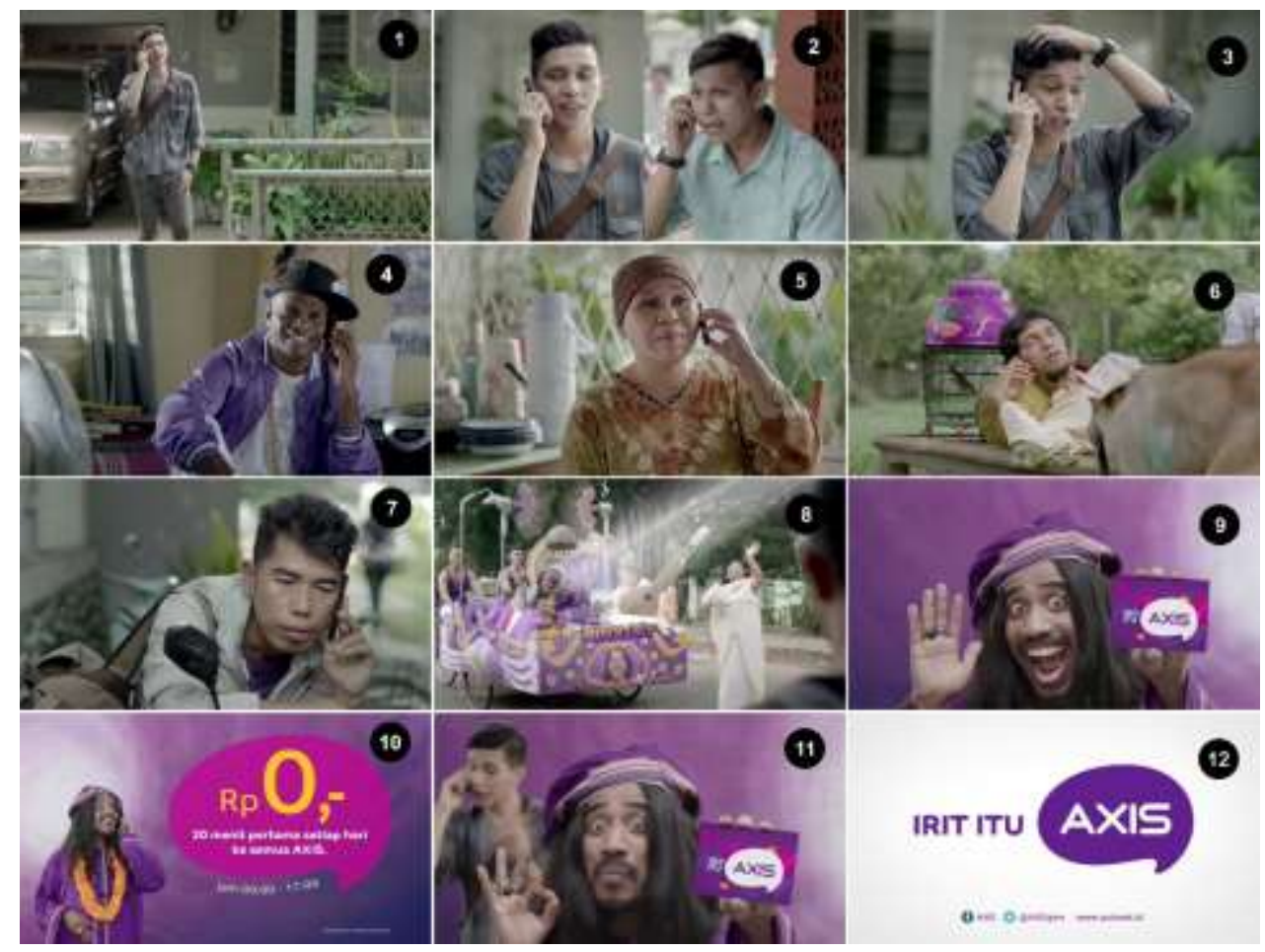

Gambar 1.1 Cuplikan Iklan Axis Serial Iritology No. 36 -Maha Guru Irit (Sumber : Iklan Axis Iritology No. 36-Maha Guru Irit, 2015) 
Deskripsi iklan televisi Axis serial Iritology No. 36 - Maha Guru Irit yang pertama menceritakan seorang mahasiswa atau pekerja yang ingin menumpang ke Jalan Sudirman ke beberapa orang. Dalam iklan tersebut, terlihat beberapa orang yang ditelpon oleh pemuda tersebut. Dalam scene terlihat beberapa orang dengan penampakan wajah dan logat dari berbagai daerah yang ditampilkan seolah menegaskan bahwa produk provider Axis sangat efektif untuk menelpon ke berbagai daerah sekalipun. Iklan Axis serial pertama membahas tentang kehematan menelpon diberbagai daerah tanpa henti. Sampul iklan dalam iklan pertama Axis serial Iritology menampilkan seorang penarik becak yang sedang bersantai seolah tidak mengalami beban apapun. Iklan ini telah dilihat lebih dari 1.050.162 kali di Channel Youtube.

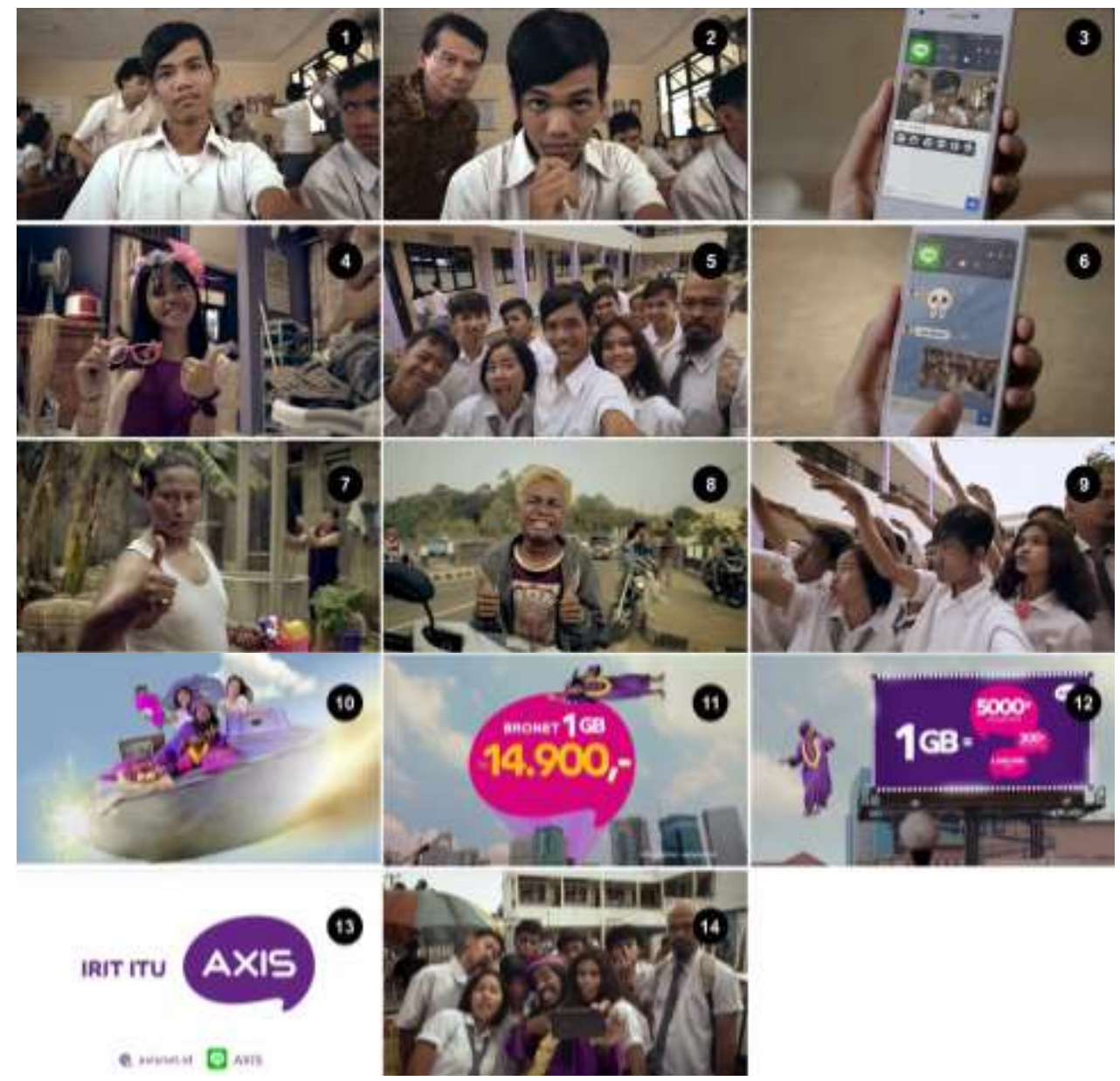

Gambar 1.2 Cuplikan Iklan Axis SerialIritology No. 54 - Cekrek Upload (Sumber : Iklan Axis Iritology No. 54 - Cekrek Upload, 2015) 
Iklan Axis kedua serial Iritology No. 54 - Cekrek Upload pertama kali ditayangkan pada tanggal 27 November 2015 yang telah ditonton sebanyak 145.935 kali di Channel Youtube Axis dan lebih dari 47 ribu subscriber. Iklan kedua menceritakan tentang remaja SMA yang dibuka dengan pedagang cilok dengan setting di depan sekolah menengah atas untuk membuka iklan. Setting kedua dengan setting ruang kelas yang cukup ramai dengan berbagai murid yang sedang bercanda. Dalam iklan tersebut diperlihatkan seorang remaja yang sedang menunggu guru dengan selfie atau mengambil gambar sendiri dengan berbagai gaya yang tidak menyadari keberadaan guru dibelakangnya. Kemudian ia mengunggahnya di media sosial miliknya. beberapa teman dalam sosial media miliknya menyukai postingan yang telah diunggah oleh remaja tersebut. Tidak sampai remaja tersebut memang senang sekali untuk mengunggah selfie dirinya bersama teman-temannya di media sosial miliknya.

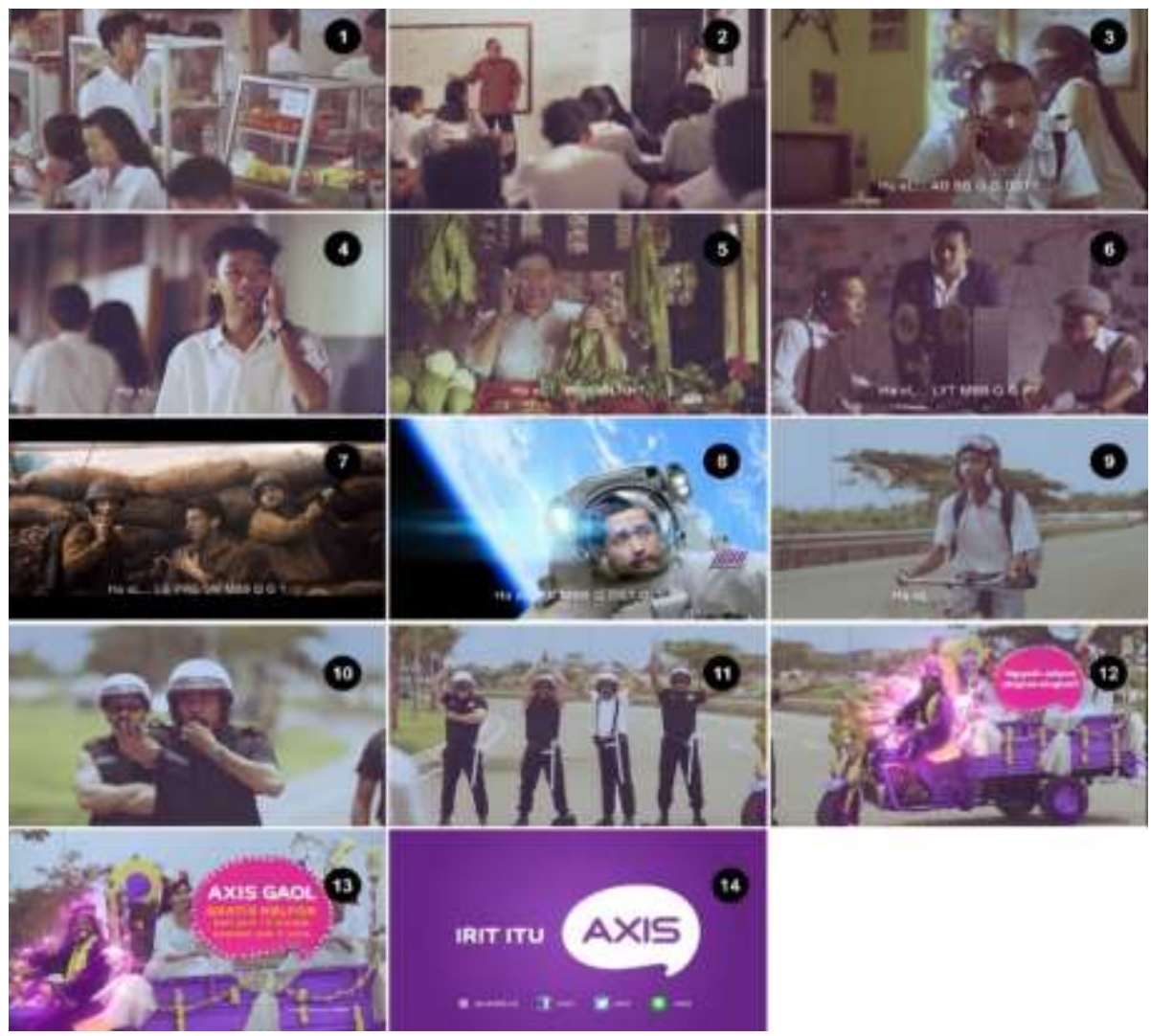

Gambar 1.3 Cuplikan Iklan Axis Serial Iritology No. 72 Axis Gaol \#HaeeeL (Sumber : Iklan Axis Iritology No. 72 Axis Gaol \#HaeeeL, 2016) 
Serial Iritology iklan Axis yang ketiga masih dengan tema yang sama yang mengulik remaja SMA dengan berbagai latar yang ditampilkan. Iklan serial ketiga dirilis pada tanggal 29 Februari 2016 yang sudah dilihat lebih dari 1.553 .607 kali di channel youtube Axis. Dalam serial iklan ini dengan menampilkan seorang ibu yang berdandan sederhana yang nampak bingung dan terdapat efek suara "aktion buk, aktion!. Scene selanjutnya memperlihatkan siswa sekolah menengah yang berkeliling sekolahnya mencari kekasih dengan mnyebutnya, bebeb. Siswa tersebut mencari diberbagai tempat disekolah seperti di kantin, ruang kelas dan kemudian siswa tersebut menelpon beberapa orang dengan setting tempat yang berbeda-beda dengan ucapan yang ia singkat membuat beberapa orang yang ditelponnya menampilkan ekspesi tidak mengerti atas perkataan siswa tersebut. Serial ketiganya menawarkan kemurahan dalam tarif telepon sehingga penggunanya tidak perlu khawatir dengan tarif telepon yang dibebankan dengan menyingkat pembicaraan yang membuat penerimanya sulit untuk menangkap pesan yang disampaikan. Berbagai setting latar yang dipakai untuk menjelaskan keadaan tokoh utama yaitu remaja SMA yang sengaja dipakai untuk menjelaskan tentang upaya menghemat paket telepon untuk menelpon kekasihnya. 


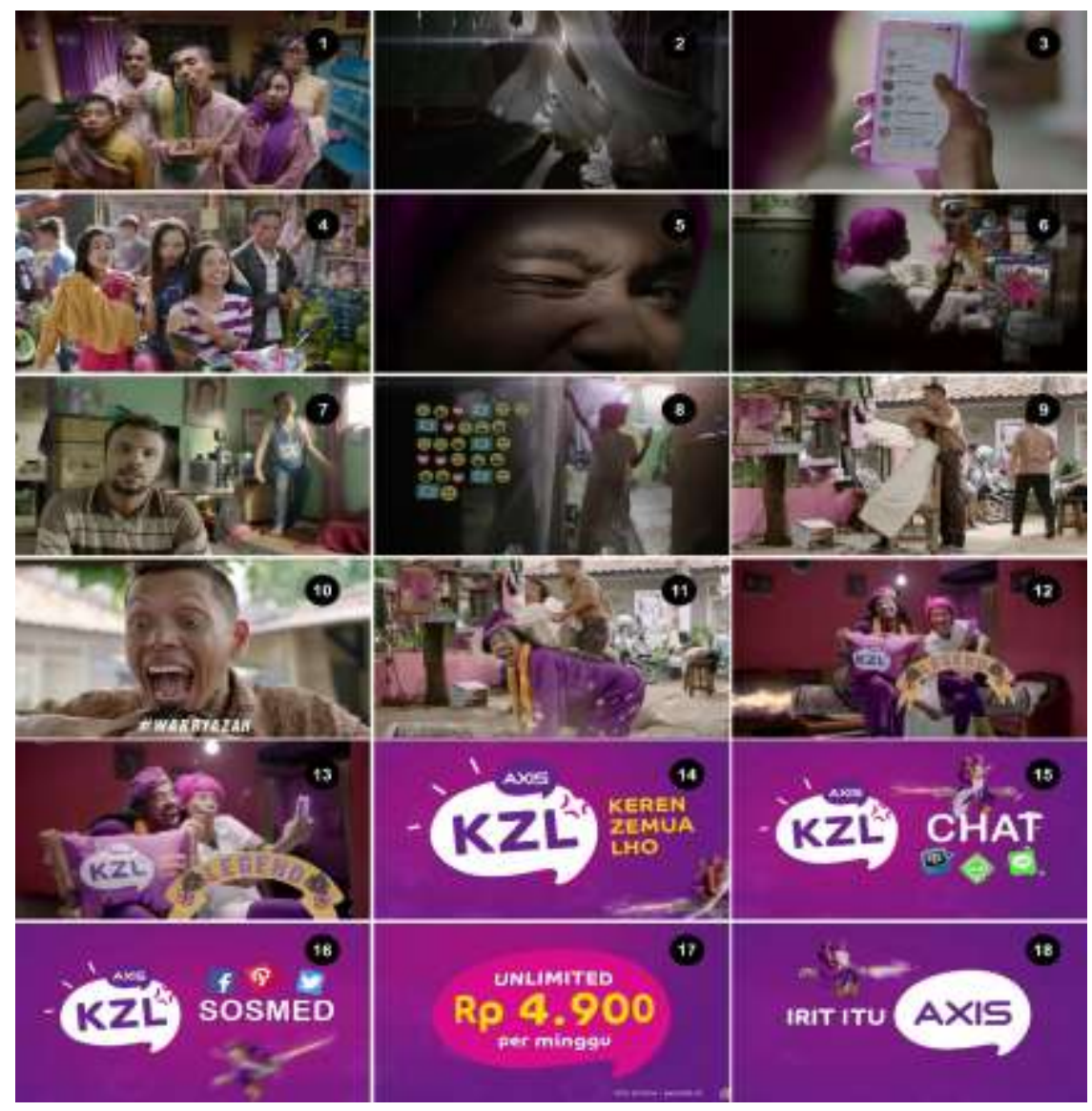

Gambar 1.4 Cuplikan Iklan Axis Serial Iritology No. 81 - Axis KZL \#Warbyasah (Sumber : Iklan Axis Iritology No. 81 - Axis KZL \#Warbyasah, 2017)

Serial iklan Iritology yang terakhir dengan nama Iritology No. 81 - Axis KZL \#Warbyasah dengan opening iklan berupa ilustrasi bak truk yang diilustrasikan dengan gambar seorang laki-laki dengan pose badan dan wajah yang sengaja dibuat berbeda, mimik wajah dengan ekspresi menggoda dan badan yang dibuat sedikit bergoyang kekanan dan kekiri dengan warna latar berwana ungu. Adegan selanjutnya menampilkan sebuah keluarga yang hendak pergi tarawih yang dapat dilihat dari atribut sekeluarga yang mengenakan baju koko dan juga membawa mukena. Keluarga itu tampak unik dengan rambul yang dibuat poni memanjang kedepan sebagai salah satu gaya yang hits pada masa itu. Momen tersebut dapat dilihat dari tanggal rilis iklan keempat Axis serial Iritology yaitu pada tanggal 1 Juni 
2016 yang seminggu lagi menuju bulan Ramadhan.Iklan ini telah ditonton lebih dari 1.842.617 viewers dengan tanggal rilis 1 Juni 2016 di Channel Youtube.

Fenomena budaya dapat terlihat dari beberapa cuplikan Iklan Axis serial Iriotology sehingga menarik target audien yang disasar pada produk ini. Pengemasan iklan yang lugas dalam menyampaikan pesan iklan membuat iklan serial Axis mudah masuk di kalangan masyarakat. Penggambaran set dan latar yang dipakai seperti menggambarkan fenomena masyarakat yang memang terjadi sehari hari. Kemudian penelitian ini memakai pembahasan pendekatan iklan dalam bentuk format, struktur, gaya dan teknik iklan (Vilanilam dan Varghese, 2004) yang membuat iklan televisi ini banyak diminati masyarakat serta parodi dalam iklan Axis seril Irirtology

Pada iklan televisi Axis serial Iritology yang pertama menggunakan bentuk format iklan problem solution dan slice of life yang bisa dilihat dari cuplikan scene pertama yang menggambarkan kegiatan keseharian seorang laki-laki yang ingin menumpang ke jalan Sudirman. Pendekatan problem solution format dapat dilihat dari perilaku tokoh utama yang mencoba menelpon beberapa orang dengan karakteristik yang berbeda-beda untuk menuntaskan permasalahannya. Sesuai dengan cirinya dalam problem solution format dengan metode storytelling yang menghadirkan permasalahan pada awal scene kemudian terdapat solusi setelah tokoh utama menelpon beberapa orang dan terdapat satu orang yang bersedia ditumpangi tokoh utama untuk ke tujuan jalan Sudirman. Pada scene ke 00.00.25 memperlihatkan burlesque format dengan menampilkan pembuka mascot iklan yang berlebihan dengan menaiki odong-odong yang dikawal beberapa laki laki serta pengiring perempuan yang memainkan musik dan terpapar sinar dari langit seperti memperlihatkan sebuah ilham. Scene ke 00.00.29 menggunakan testimonial format yang memperlihatkan maskot Axis yang dibelakangnya terdapat pemeran utama iklan yang menelpon berulang kali, format ini salah satu cirinya yaitu pengungkapkan pengalaman dalam menggunakan produk tersebut.

Dilihat dari struktur iklan, dalam iklan televisi Axis Iritology No. 36 menggunakan struktur Vignettes karena terdapat perubahan sikap dari tokoh utama yang berubah-ubah dari pertama yang kebingungan mencari tumpangan, sampai kemudian menelepon beberapa orang dengan sifat yang berbeda dan sampai 
akhirnya mendapatkan tumpangan. Pendekatan gaya dan teknik dalam iklan televisi Axis Iritology No. 36 menggunakan gaya comedy dimunculkan dalam scene saat tokoh utama mulai menelpon beberapa orang dengan jawaban yang beragam. Teknik iklan yang dipakai adalah animasi pada awal scene pertama 00.00.00, pada detik ke 00.00.30 dimana iklan penawaran tentang produk dimunculkan dan pada penutup iklan masih menggunakan teknik animasi yang meperlihatkan slogan produk. Teknik special effect pada scene 00.00.25 yang terdapat sinar dari langit seoalah memacarkan suatu inspirasi atau pencerahan saat promosi produk.

Iklan televisi Axis kedua serial Iritology yang menggunakan bentuk format iklan slice of life, burlesque format, dan testimonial format yang bisa dilihat dari scene pertama yang menggambarkan kegiatan keseharian seorang pelajar yang sedang menunggu gurunya dikelas dengan berfoto atau selfie. Pelajar tersebut memiliki jenjang pertemanan yang cukup luas di media sosial miliknya terbukti dengan beberapa teman yang mengikuti kegiatan di media sosial pemuda tersebut dengan karakteristik yang berbeda. Pendekatan burlesque format ditampilkan dengan teknik special effect pada kemunculan ikon produk dan promo produk Axis seolah menggambarkan batu meteor yang akan jatuh ke bumi membawa sebuah kabar baik. Dan testimonial format ditampilkan pada scene saat pemuda tersebut mengunggah fotonya di media social berulang kali, struktur iklan, dalam iklan televisi Axis Iritology No. 54 menggunakan struktur Comparison dengan mendemonstrasikan kehebatan produk Axis yang cocok digunakan kalangan remaja dengan tarif internet hemat yang diperlihatkan dari awal seorang pelajar yang kerap kali berselancar di media sosial tanpa takut biaya internet mahal. Dan struktur continue series diperlihatkan pada scene pertama detik 00.00.00 dengan memiliki tema sampul sama seperti serial sepbelumnya yaitu Iritology No. 36-Maha Guru Irit. Pendekatan gaya dalam iklan televisi Axis Iritology No. 54 menggunakan gaya comedy dimunculkan dalam scene saat tokoh utama berfoto dengan berbagai gaya dan berbagai macam pertemanan di media sosial miliknya. Dan teknik animasi diperlihatkan mulai dari detik 00.00.23 yang memuat promo produk tersebut serta pada akhir scene untuk tagline produk. 
Serial iklan televisi ketiga Axis menggunakan bentuk format iklan problem solution, slice of life dan burlesque format. Slice of life format dimunculkan dari scene pertama yang menggambarkan seorang pelajar yang mencari kekasihnya dengan menelpon yang disingkat-singkat dalam berbagai latar tempat. Pelajar tersebut menelpon dengan mempersingkat percakapan telepon yang membuat orang penerima telepon tidak mengerti akan maksud pelajar tersebut. Dan problem solution format dimunculkan pada scene iklan promo produk sebagai pemecahan masalah pelajar tersebut yang menelpon dengan disingkat untuk meperhemat tarif telepon. Hal tersebut bisa terjadi sebagai trik untuk menghemat tarif menelpon. Kemudian pendekatan burlesque forma tjuga ditampilkan dengan teknik special effect pada berbagai latar orang penerima telepon dari situasi berperang, hingga astronot diluar angkasa. Struktur iklan, dalam iklan televisi Axis Iritology No. 72 menggunakan struktur vignettes dan continue series yang dapat dilihat perubahan sikap penerima telepon yang terlihat bingung dengan ucapan tokoh utama yang berbicara dengan menyingkat kata-kata untuk mencari kekasihnya dengan latar yang berbeda dan tema pembuka iklan yang dibuat sama dengan serial sebelumnya. Pendekatan gaya iklan televisi Axis Iritology No. 72 menggunakan gaya comedy dan fantasy dimunculkan dalam semua scene saat tokoh utama mulai menelpon kekasihnya dengan ucapan yang disingkat. Selain pada scene latar medan perang dan luar angkasa, teknik animasi dan special effect digunakan saat akan memunculkan promo produk menelpon murah yang diperlihatkan dari maskot produk yang menaiki gerobak motor yang berkilau seolah pencerahan atas masalah tokoh utama dan pada saat promo layanan produk ditampilkan.

Iklan televisi Axis serial Iritology yang terakhir menggunakan bentuk format iklan slice of life, burlesque dan testimonial format. Slice of life format dimunculkan dari cuplikan scene pertama yang menggambarkan keluarga yang hendak menunaikan ibadah taraweh dengan atribut mukena, sarung lengkap yang sedang membicarakan seorang pemuda yang begitu famous. Hal tersebut bisa dilihat dari tanggal rilis iklan keempat Axis serial Iritology pada tanggal 1 Juni 2016 yang seminggu lagi menuju bulan Ramadhan. Scene berikutnya merupakan komentar dari beberapa orang dengan latar dan juga profesi yang berbeda. Pendekatan burlesque format dilihat dari beberapa 
komentar orang yang menilai tokoh utama dengan ekspresi berlebihan yang mengarah pada rasa kekaguman. Dan testimonial format terlihat dari scene detik ke 00.00.06 dan 00.00.20 saat pemeran utama iklan memperlihatkan keaktifan di jejaring sosial medianya. Struktur iklan dalam iklan televisi Axis Iritology No. 81 menggunakan struktur Vignettes dan continue series karena terdapat perubahan sikap dari tokoh pendamping yang berubah-ubah yang mengagumi tokoh utama serta tema pembuka masih sama dengan tema iklan serial sebelumnya. Pendekatan gaya dan teknik dalam iklan televisi Axis Iritology No. 81 menggunakan gaya comedy dan fantasy dimunculkan dalam scene saat orang-orang mulai berkomentar tentang tokoh utama dan pada scene menuju akhir di mana tokoh utama menaiki karpet gulung terbang bersama dengan maskot produk Axis. Teknik iklan yang dipakai adalah animasi dan special effect pada kemunculan maskot yang secara tiba tiba muncul di tengah masyarakat dan pada scene tokoh utama menaiki karpet gulung terbang serta membawa promosi produk Axis. Promo layanan produk terbaru menggunakan teknik animasi yang dimulai dari scene 00.00.36 serta teks pendukung pada pertengahan iklan yang mencamtumkan hastag produk warbyasah.

Parodi pada Iklan Televisi Axis Serial Iritology yang pertama adalah Iritology No. 36 - Maha Guru Irit. Pada iklan serial Irirotlogy yang pertama didapatkan kesimpulan data dengan pendekatan format, struktur, gaya, dan teknik iklan sebagai berikut. 


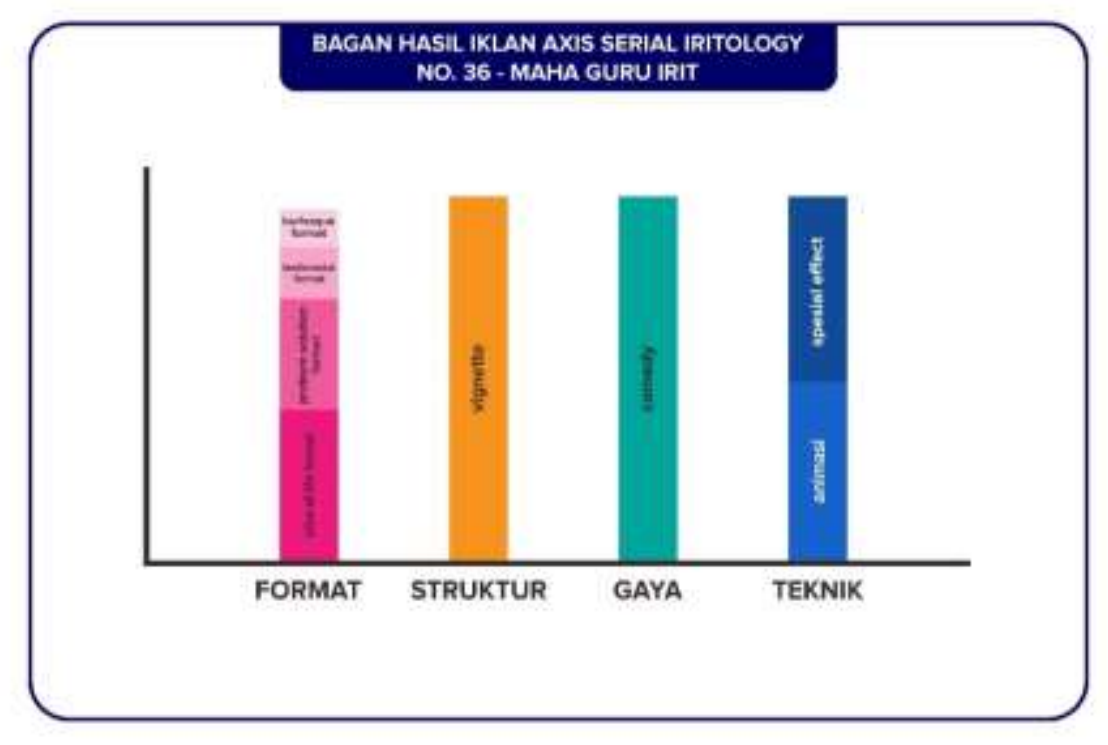

Bagan 3.1 Hasil PersentasePendekatan Iklan Axis Serial Iritology No. 36

Dari bagan persentase di atas dapat disimpulkan bahwa iklan Axis serial Iritology menggunakan gaya iklan comedy yang mendominasi dan dapat terlihat dari peradeganan ang menunjukkan realitas masyarakat pinggiran perkotaan yang dibuat dengan humor untuk menarik masyarakat akan produk Axis dengan konten yang ringan. Format iklan yang dipakai merupakan gabungan dari slice of life dan problem solution format dengan tambahan teknik special effect. Unsur parodi pada iklan Axis dapat dilihat dari beberapa scene sebagai berikut ini.

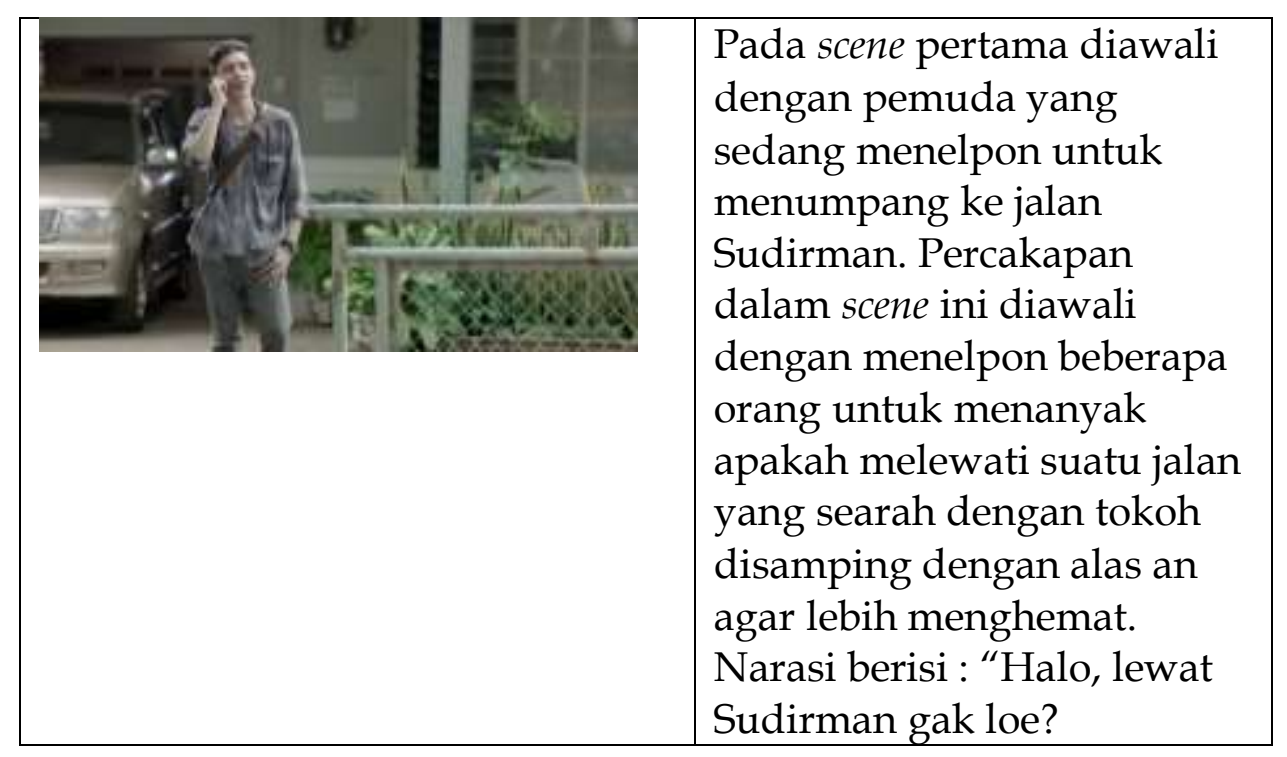




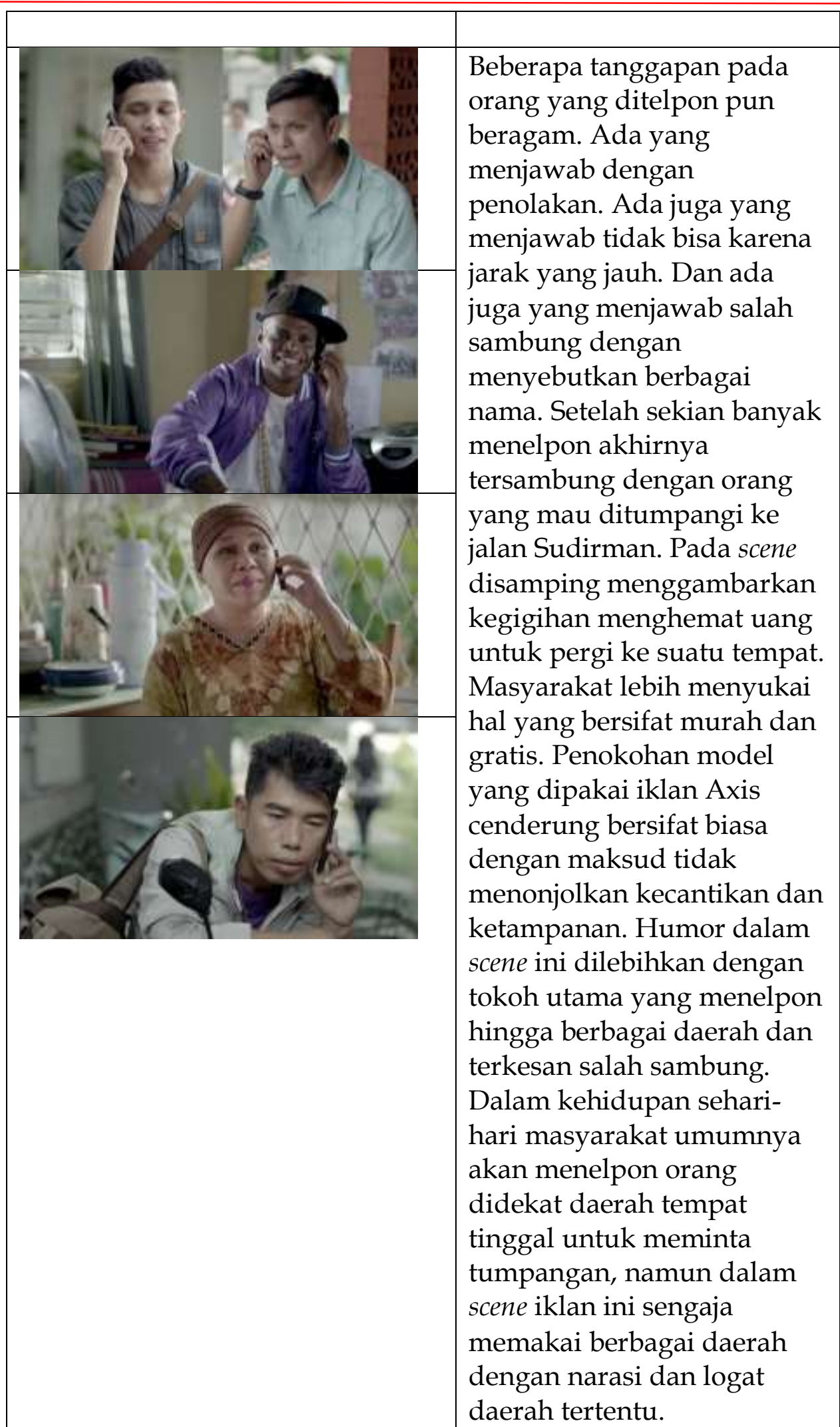




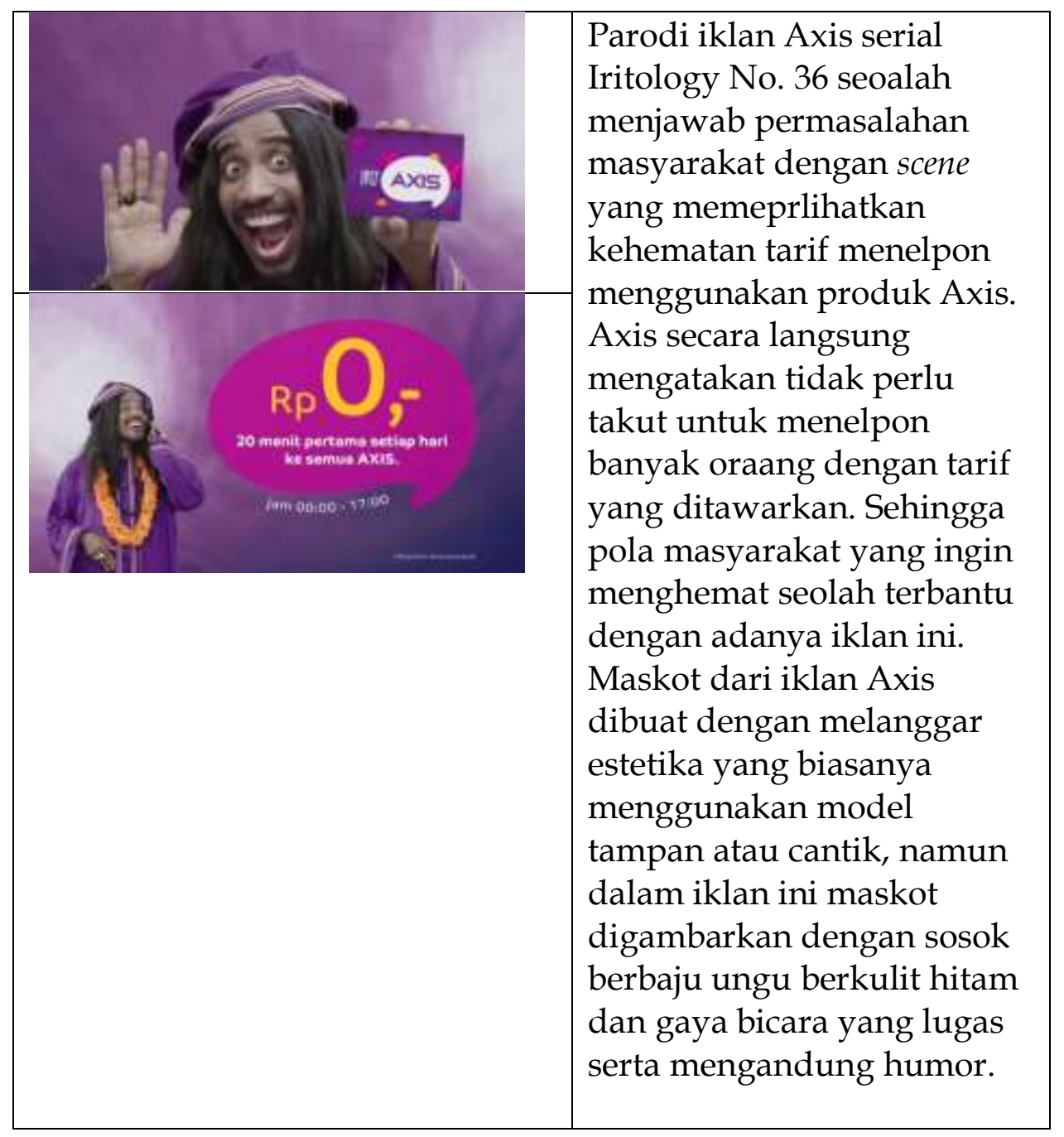

Efektivitas iklan parodi membuat masyarakat konsumtif sadar merek dan mampu menarik banyak masyarakat yang menjadi target audien ataupun diluar sasaran target audien. Pendekatan iklan yang dipakai untuk iklan Axis serial Iritology No. 36 mendukung untuk terbentuknya sebuah iklan parodi yang unsur utama dalam iklan menggunakan gaya komedi. Fenomena masyarakat pada iklan Axis serial pertama ini menunjukkan sebuah kritikan akan masyarakat yang pada umumnya menyukai suatu hal yang bersifat murah bahkan gratis. Untuk itu, produk Axis masuk dan mendukung fenomena tersebut dengan meluncurkan kemurahan dalam tarif telepon. Sehingga Axis langsung menyasar pada perilaku masyarakat menengah kebawah yang konsumtif namun tetap dapat berhemat. Pemeranan tokoh dalam iklan Axis tergolong menggunakan masyarakat pada umumnya yang tidak menampilkan sisi ketampanan ataupun kecantikan. Pemilihan tokoh 
iklan dari berbagai daerah dengan logat dan karesteristik wajah serta narasi yang dibuat memang tidak berkesinambungan menjadikannya jenaka.

Iritology No. 54 - Cekrek Upload adalah Iklan kedua Axis serial Iritology dengan judul Iritology No. 54 - Cekrek Upload telah didapatkan hasil dari pendekatan format, struktur, gaya dan teknik iklan sebagai berikut.

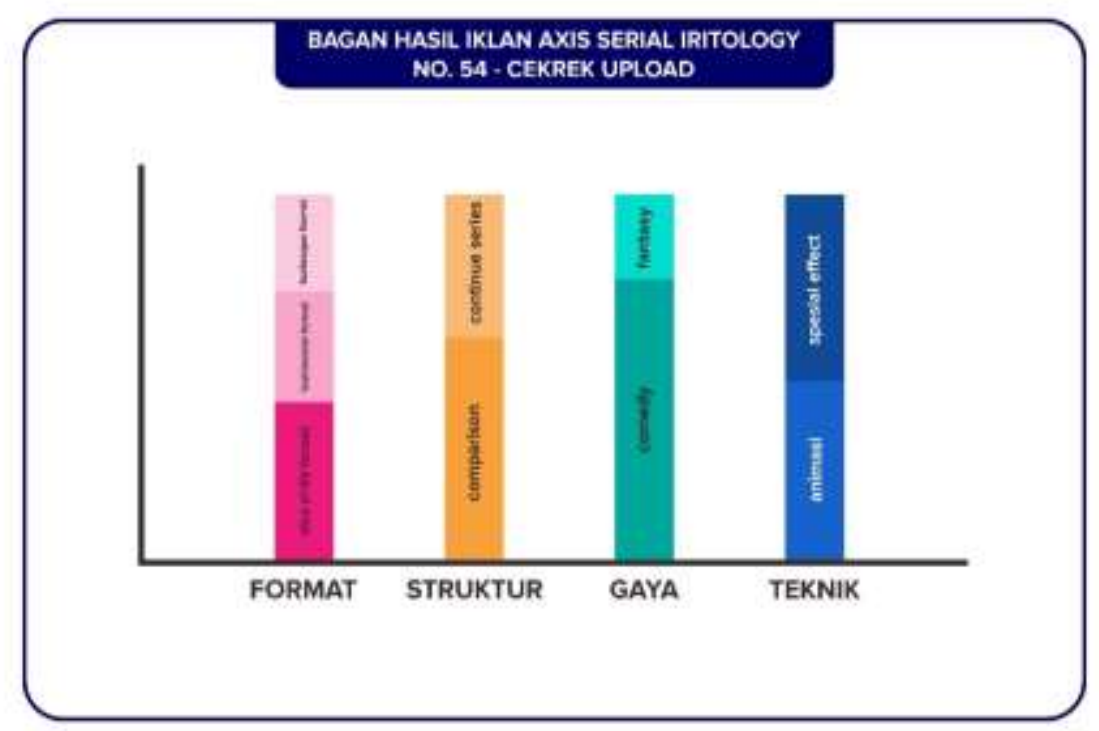

Bagan 3.2 Hasil PersentasePendekatan Iklan Axis Serial Iritology No. 54

Persentase diatas menunjukkan pendekatan format iklan slice of life cukup mendominasi dan digabungkan dengan burlesque format. Gaya iklan didominasi oleh comedy, fantasy pada akhir scene nya dengan teknik special effect dan stuktur iklan comparison yang memperlihatkan kehebatan produk Axis. Parodi pada iklan dapat dilihat dari beberapa scene berikut.

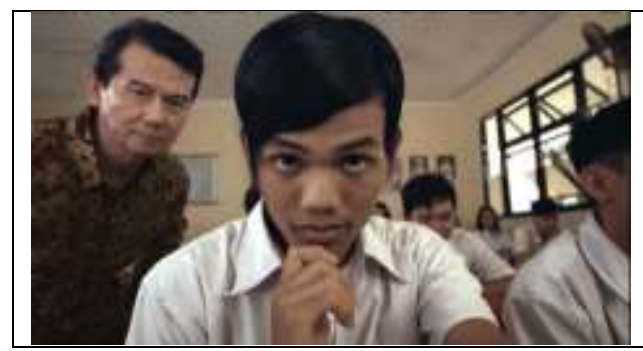

Scene dalam iklan ini memperlihatkan seorang siswa yang sedang menunggu gurunya dengan berswafot dengan narasi jenaka :"nunggu guru, selfie dulu. Ganteng dikit, cekrek. Ganteng 


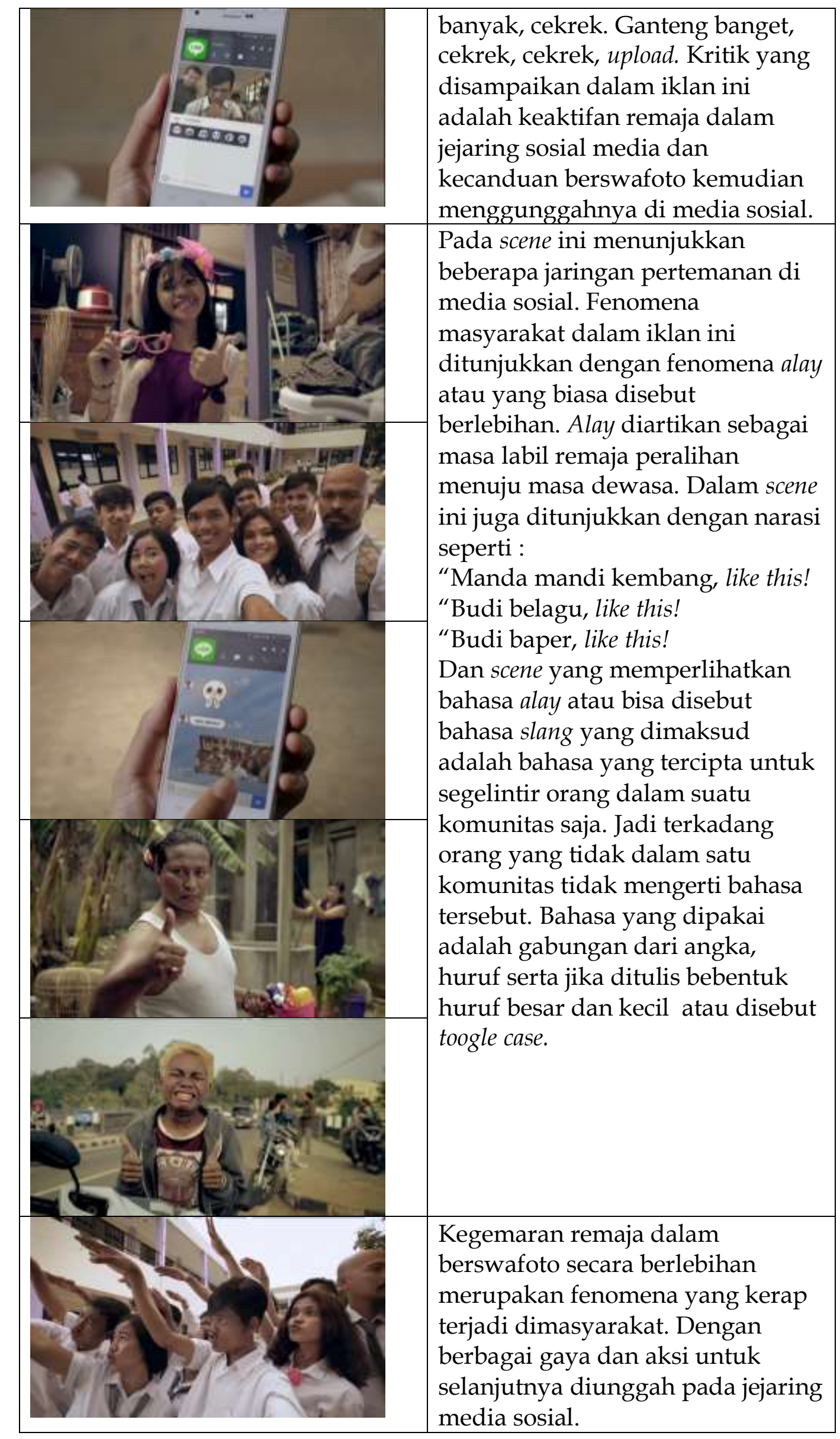




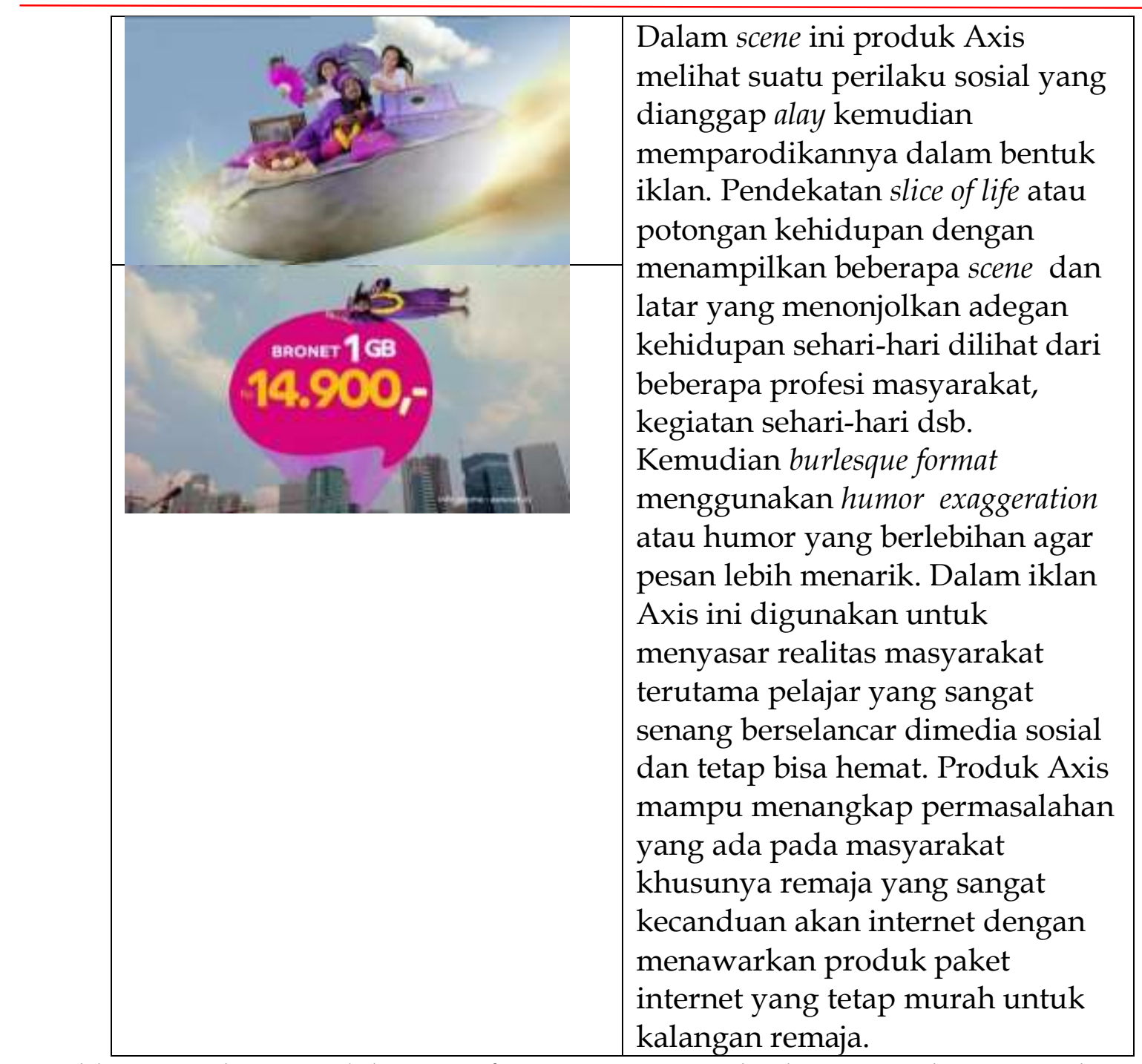

Iklan parodi mengolah suatu fenomena yang ada di masyarakat menjadi suatu humor dan menyelipkan promosi produk di dalamnya sehingga masyarakat merasa tidak tersinggung akan kritikan yang ada dan menyadari adanya fenomena alay yang dirasa sebagaian masyarakat mengganggu namun benar adanya fenomena tersebut. Pendekatan iklan yang dipakai untuk iklan Axis serial Iritology No. 54 menggambarkan realitas masyarakat yang sebenarnya dengan adanya fenomena alay yang diangkat dalam sebuah iklan. Gaya comedy masih digunakan iklan Axis dengan tambahan gaya fantasy di akhir scene yang memperlihatkan produk Axis seolah memberikan dukungan dengan produknya paket internet murah sehingga target audien yang disasar bisa terpengaruh. Iklan parodi Axis seolah mengatakan Axis mendukung segala ke-alay-an masyarakat dengan menyediakan tarif paket internet yang hemat. 
Iklan ketiga Axis serial Iritology dengan judul Iritology No. 72 - Axis Gaol \#Haeeel yang merupakan setema dengan iklan Axis sebelumnya yaitu Iritology No. 54 Cekrek Upload telah didapatkan hasil dari pendekatan format, struktur, gaya, dan teknik iklan sebagai berikut.

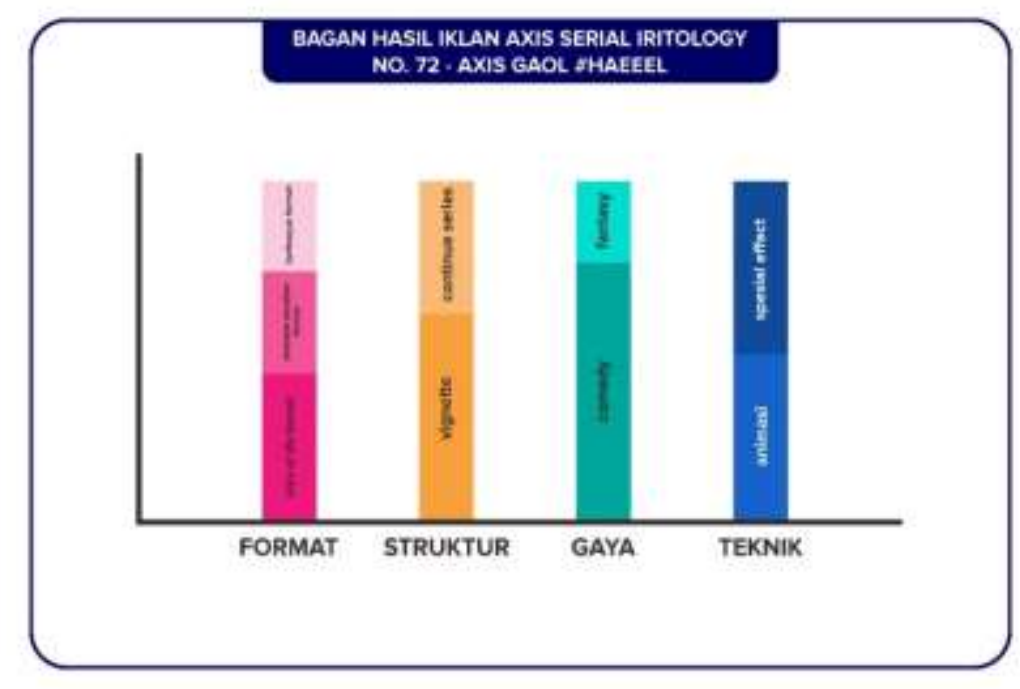

Bagan 3.3 Hasil PersentasePendekatan Iklan Axis Serial Iritology No. 72

Bagan persentase di atas menunjukkan pendekatan format iklan slice of life dan digabungkan dengan burlesque format. Gaya iklan comedy masih mendominasi ilan televisi Axis Serial Iritology dan digabungkan dengan gaya iklan fantasy. Teknik special effect dan stuktur iklan vignette digunakan untuk iklan Axis Serial Iritology No. 72. Iklan parodi ditunjukkan dari beberapa scene sebagai berikut.

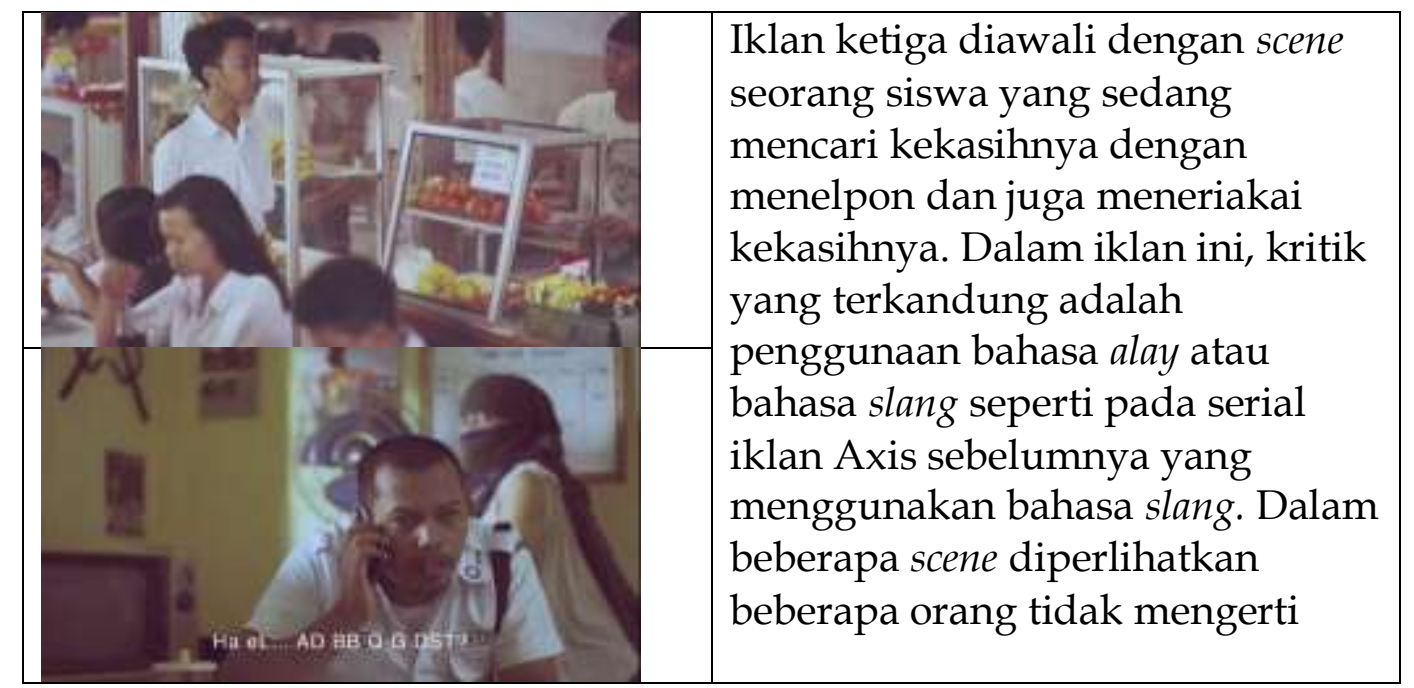




\begin{tabular}{|c|c|}
\hline 6 & $\begin{array}{l}\text { akan bahasa yang dikatakan oleh } \\
\text { remaja tersebut. Beberapa seting } \\
\text { latar yang digambarkan dalam } \\
\text { iklan seolang mempertegas bahwa } \\
\text { bahasa alay atau slang sulit } \\
\text { dipahami kebanyakan orang. } \\
\text { Fenomena penggunaan bahasa ini } \\
\text { biasanya digunakan oleh } \\
\text { komunitas alay dan dalam } \\
\text { telekomunikasi untuk menghemat } \\
\text { tarif telepon juga perpesanan. } \\
\text { Seperti yang telah dibahaskan } \\
\text { sebelumnya, bahasa alay atau slang } \\
\text { hanya bisa dipahami oleh } \\
\text { sekelompok orang dalam } \\
\text { komunitas yang sama mengerti } \\
\text { untuk komunikasi antar sesama } \\
\text { komunitas. Namun, tidak berlaku } \\
\text { untuk orang di luar komunitas } \\
\text { tersebut akan sulit mengerti } \\
\text { bahasa alay atau slang. Tokoh } \\
\text { utama dalam iklan serial ini tidak } \\
\text { jauh berbeda dengan iklan } \\
\text { sebelumnya yaitu tokoh yang } \\
\text { terlihat biasa atau bahkan dibuat } \\
\text { lebih jelek dari kehidupan } \\
\text { masyarakat sehari-hari dengan } \\
\text { narasi jenaka. Scene melebihkan } \\
\text { realitas yang ada dimasyarakat } \\
\text { dengan tokoh utama yang } \\
\text { menelpon ke beberapa orang } \\
\text { dengan situasi yang berbeda, } \\
\text { seperti saat dipeperangan, di luar } \\
\text { angkasa, dan juga disiaran radio. }\end{array}$ \\
\hline करे & $\begin{array}{l}\text { Dalam hal ini, iklan parodi Axis } \\
\text { memproduksi suatu yang } \\
\text { dianggap fenemena bahasa alay } \\
\text { menjadi iklan parodi yang banyak } \\
\text { diminati masyarakat. } \\
\text { Pendekatanslice of life atau }\end{array}$ \\
\hline
\end{tabular}




\begin{tabular}{|l|l|} 
potongan kehidupan dengan \\
menampilkan beberapa scene dan \\
latar yang menonjolkan adegan \\
kehidupan sehari-hari yang \\
ditampilkan pada kehidupan \\
dipasar, sekolahan dan jalanan \\
kemudian ditambah dengan \\
burlesque format menggunakan \\
humor exaggeration atau humor \\
yang berlebihan seperti ekspresi \\
bingung dan juga latar scene yang \\
dilebihkan seperti latar di luar \\
angkasa, medan perang yang ada \\
beberapa dalam iklan Axis ini \\
digunakan untuk salah satu \\
segementasi target audien yaitu \\
pelajar yang sering kali berusaha \\
hemat dalam bertelekomunikasi \\
dengan teman, kekasih atau \\
komunitasnya.
\end{tabular}

Iklan Axis serial Iritology No. 72 mengkomunikasikan suatu fenomena yang ada di masyarakat menjadi sebuah peluang untuk menyasar target audien melalui pendekatan humor dan kemudian menyelipkan promosi produk di dalamnya. Bahasa alay yang dimuat dalam iklan tersebut solah untuk sindiran bagi masyarakat yang takut menelpon dengan tarif mahal sehingga mepersingkat perkaatan membuat orang yang menerima telepon tidak paham akan maksud yang diucapkan. Pada iklan Axis serial Iritology No. 72 ini memanfaatkan fenomena yang ada menjadi iklan yang menarik masyarakat dengan penawaran tarif iklan yang relatif murah sehingga tidak perlu takut untuk menelpon dengan mempersingkat percakapan.

Iklan yang terakhir adalah Iritology No. 81 dengan judul Iritology No. 81-Axis KZL \#Warbyasah yang rilis awal seminggu sebelum bulan Ramadhan 2016. Persentase data dalam Iklan Axis serial iritology No. 81 adalah sebagai berikut. 


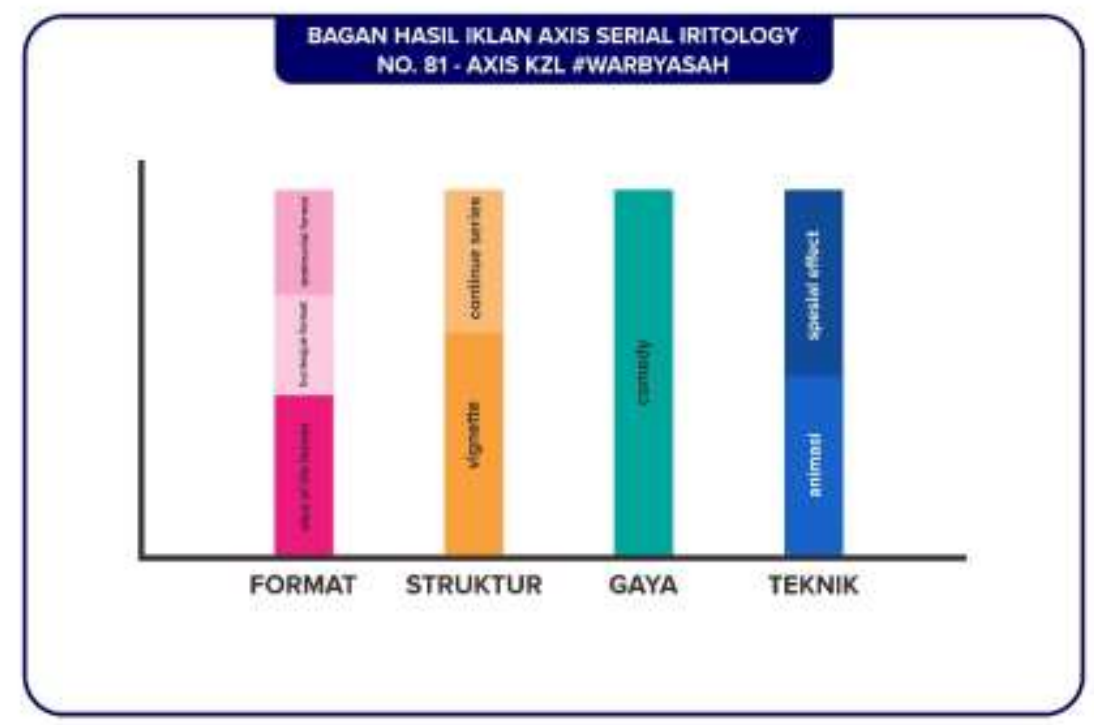

Bagan 3.4 Hasil Persentase Pendekatan Iklan Axis Serial Iritology No. 81

Persentase diatas menunjukkan pendekatan format iklan slice of life dan probelem solution format dipakai untuk iklan Axis serial Iritology yang terakhir. Gaya iklan comedy masih mendominasi iklan televisi Axis Serial Iritology. Teknik special effect dan stuktur iklan vignette juga masih digunakan untuk iklan Axis Serial Iritology No. 81. Iklan parodi ditunjukkan dari beberapa scene sebagai berikut.

Dalam scene pertama yang
dimunculkan adalah
keluarga dengan gaya
rambut poni belah samping
yang panjang. Kritik yang
disampaikan adalah
fenomena alay. Fenomena ini
dulu muncul karena ada
salah satu personil and
Indonesia yang memotong
rambutnya dengan gaya
poni samping yang
memanjang kemudian dicat
warna pirang. Hal tersebut
mengundang berbagai
gunjingan karena tidak




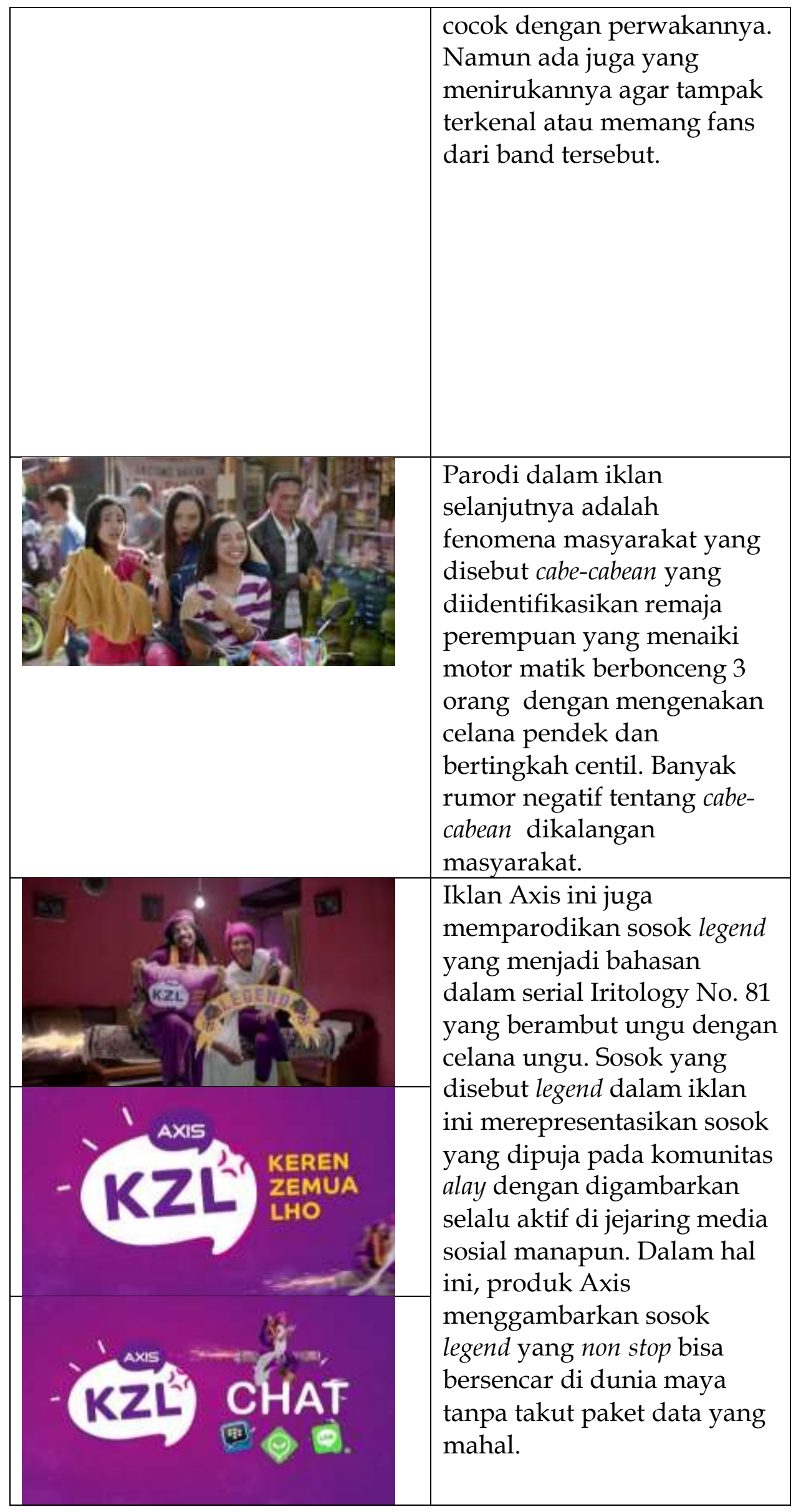


Serial terakhir iklan televisi Axis dengan judul Iritology No. 81- Axis KZL \#Warbyasah memparodikan fenomena masyarakat tentang suatu gaya yang dianggap alay dan fenomena cabe-cabean. Dalam hal ini, Axis juga menampilkan sosok yang disebut legend karena menjadi admin dimanapun ia menggunakan media sosial. Fenomena yang ada dimasyarakat dibuat dengan humor sehingga tidak membuat pihak atau komunitas yang bersangkutan tersinggung. Produk Axis mampu masuk dikalangan komunitas yang dianggap alay dengan menawarkan paket internet murah untuk berselancar di dunia maya. Pendekatan iklan yang dipakai dengan format slice of life dan gabungan problem solution membuat iklan ini mampu memecahkan permasalahan kebutuhan paket internet di masyarakat. Gaya comedy yang digambarkan dalam produk Axis seoalah mengajak masyarakat untuk menertawakan relaitas yang memang terjadi di masyarakat dan juga sebuah penerimaan akan adanya suatu hal yang dianggap buruk menjadi suatu yang dianggap bagus dengan beberapa sudut pandang dalam penyampaian iklan.

\section{KESIMPULAN}

Parodi dalam iklan dapat menjadi sebuah daya tarik tersendiri dalam penyajian sebuah iklan. Iklan akan menjadi hal yang menarik dan mudah diingat masyarakat dengan sajian konten yang ringan namun sebenarnya sarat akan kritikan. Masyarakat yang melihatnya tidak merasa digurui atau pun tersinggung dengan penyajian iklan parodi yang menggambarkan problematika kehidupan sehari-hari. Iklan dirasa cukup efektif muncul sebagai pemecah permasalahan yang ada di tengah masyarakat. Pendekatan iklan dari segi format, struktur, gaya dan tenik dalam sebuah iklan mampu mengefektifkan pesan yang diangkat dalam iklan untuk disampaiakan pada target audien. Konsep parodi pada iklan ditambah dengan beberapa pendekatan format, struktur, gaya dan teknik membuat sebuah iklan lebih efektif untuk penyampaian pesan pada masyarakat. Parodi pada iklan televisi Axis serial Iritology menampilkan problematika kehidupan sehari-hari yang dikemas dalam humor dengan pendekatan iklan yang baik, tokoh yang dibuat jenaka dengan tidak memperlihatkan sisi kecantikan maupun ketampanannya. Konten kritik pada iklan 
Axis serial Iritology tidak membuat masyarakat yang melihatnya menjadi tersinggung, namun seolah membenarkan adanya kejadian atau fenomena yang terjadi memang benar adanya. Masyarakat merasa terhibur akan iklan parodi dengan humor mengenai keseharian kehidupan mereka yang dibuat berlebihan.

Pendekatan iklan dengan format problem solution, slice of life, burlesque dan testimonial format digunakan dalam iklan Axis serial Iritology. Konsep kehidupan keseharian, dengan pemecahan permasalahan dan beberapa scene dibuat dengan berlebihan, membuat iklan ini menarik masyarakat yang merupakan target audien atau diluar target audien. Struktur iklan yang digunakan adalah vignette, comparison, dan continue series digunakan untuk iklan Axis serial Iritology karena tokoh yang memerankan megalami banyak perubahan sikap, serta memperlihatkan kehebatan produk dan memiliki runtutan yang saling terhubung. Iklan Axis serial Iritology gaya yang digunakan dominan comedy, namun ada beberapa scene yang disisipkan dengan gaya fantasy. Teknik yang digunakan dalam iklan Axis serial Iritology memakai sentuhan animasi dan special effect pada bagian tengah dan akhir iklan. Pendekatan iklan yang dibuat sedemikian rupa membuat iklan televisi Axis serial Iritology menarik di masyarakat untuk memakai produk yang sesuai dengan kebutuhan masyarakat.

\section{DAFTAR PUSTAKA}

Burhan Bungin. 2008. Konstruksi Sosial Media Massa, Kekuatan Pengaruh Media Massa, Iklan Televisi dan Keputusan Konsumen serta Kritik Terhadap Peter L. Berger \& Thomas Luckmann. Jakarta : Kencana Prenada Media Grup

H. B. Sutopo. 2006. Metodologi Penelitian Kualitatif. Surakarta : Sebelas Maret University Press

Johnson, Carla, Lee Monle, 2004, Prinsip-prinsip Periklanan dalam Perspektif Global, Jakarta: Prenada.

Rama Kartamukti. 2015. Strategi Kreatif dalam Periklanan : Konsep Pesan, Media, Branding, Anggaran. Jakarta : PT. Rajagrafindo Persada

Yasraf Amir Piliang.2003. Hipersemiotika : Tafsir Cultural Studies Atas Matinya Makna. Yogyakarta:Jalasutra

Zein Mufrrih. 2015. Periklanan, Sebuah Pendekatan Praktis. Yogyakarta : Buku Litera

Apjii.com diakses pada 2 Januari 2019 pukul 11.22 WIB 
http:// www.plimbi.com/news/3471/sejarah-axis diakses pada tanggal 11 Oktober 2018 pukul 18.39 WIB

https://tekno.kompas.com/read/2014/04/08/1717055/XL.dan.Axis.Resmi.Jadi.Sat $\underline{\text { u.Perusahaan diakses pada tanggal } 23 \text { September } 2018 \text { pukul } 15.49 \text { WIB }}$ http://www.tribunnews.com/bisnis/2015/03/30/iritology-layanan-tarif-irit-axis diakses pada tanggal 3 Oktober 2018 pukul 19.38 WIB https://www.antaranews.com/berita/488239/axis-luncurkan-kampanye-gayahidup-iritology diakses pada tanggal 3 Oktober 2018 pukul 19.40 WIB https://www.xl.co.id/id/for-you/news-and-promo-detail/586/XL-Raih-IndonesiaPrestige-Brand-Award-2017 diakses pada tanggal 3 Oktober 2018 pukul 19.39 WIB https://tekno.kompas.com/read/2017/01/24/18462397/10.video.iklan.terbaik.yout ube.indonesia.juli-desember.2016 diakses pada tanggal 3 Oktober 2018 pukul 19.37 $\underline{\text { WIB }}$ 